\title{
Search for Immortality in Ancient and Modern Sport
}

Authors' contribution:

A) conception and design of the study

B) acquisition of data

C) analysis and interpretation of data

D) manuscript preparation

E) obtaining funding

\section{Jernej Pisk}

University of Ljubljana, Slovenia

ABSTRACT

There is only one real problem each human being faces: death. Nobody lives eternally. In essence, humans are mortal beings; beings-unto-death, as framed by Heidegger. But human beings are never reconciled with this fact. Since ancient times, humans have been searching for ways to become immortal and to somehow stay alive eternally. In this paper we will focus on one specific common understanding of immortality among people - immortality in memory. Since ancient Greece, success and fame have meant not only different privileges in the community but also achieving symbolic immortality. Artists, politicians, and athletes - all of them were trying to become well known. So other people would remember them after their death, praise them, and keep them in their memory. In times when transcendental immortality was not known (or accepted), this was the only means to becoming immortal. To this day, lists and statues of ancient Greek Olympic champions have survived. So in a way champions are still alive - they achieved immortality. With the rise of metaphysics in philosophy and the also the Christian understanding of transcendental immortality, the need to be famous, to stay alive in memory, has declined. But nowadays, when the faith in transcendental immortality is weak, once again the ancient notion of immortality is becoming more and more powerful. Being famous, recognized among others, staying in the memory of others - this can be one of the important motives in striving to become a champion in the field of sport.

KEYWORDS sport, athlete, immortality, recognition, fame, winning

\section{Introduction}

In 1984 Bob Goldman, founder of the National Academy of Sports Medicine in Chicago, published a book Death in the Locker Room: Steroids \& Sports. In this book he clearly presented the great danger which athletes face if they use prohibited drugs. At that time, steroids were especially very popular. In 1992 Goldman published an expanded second edition of his book entitled Death in the Locker Room II: Drugs \& Sports, in which results of very interesting research were presented. Goldman asked 198 athletes the following question:

"If I had a magic drug that was so fantastic that if you took it once you would win every competition you would enter, from the Olympic decathlon to the Mr. Universe, for the next five years, but it had one minor drawback - it would kill you five years after you took it - would you still take the drug?" (Goldman 1992, p. 24)

Out of all the athletes, 52\% indicated that they would still take this drug. The results of this survey were published in a 1997 Sports Illustrated article (Bamberger \& Yeager 1997), and have attained legendare status within the Olympic sports community. The survey became known as the Goldman Dilemma (Cannor 
\& Mazanov 2009). Goldman states that he surveyed athletes in “combative and power sports”, which are not representative of Olympic events as a whole. However, it can open many interesting question for research in sport. He surveyed hundreds of athletes biannually for a decade, from bodybuilders to Olympians to professionals ${ }^{1}$. He wanted to know how far athletes would go to win. The answer was always the same: to the grave ${ }^{2}$. Each time he has done the survey, more than half of the athletes have answered they would take the pill.

Now the fundamental question arises: Why would athletes sacrifice their health - even more, their only life - to win an Olympic medal? Some assert that the answer to this question is hidden in the huge amounts of money that they earn. But, many sports (still) do not have such financial support. Others are convinced that the challenge is to become physically perfect. However, neither money nor a perfect body is useful if this individual athlete is no longer alive. We will therefore try to answer the question of the importance of winning in sport in a slightly different way. On the basis of this interesting survey by Goldman among top-level athletes, we can conclude that simply money and physical perfection are not enough to compensate for the enormous amount of sacrifice and effort that competitive sport demands. It seems that in modern, high-level competitive sport, once again the innate desire for immortality is shown, just as it was characteristic for ancient Greek sport.

\section{Human beings in the search for immortality}

It is possible to assert that to die is a part of human essence. Every human being will sooner or later stop existing. But we feel instinctively that it is better to be than not to be. Therefore "we fear death not as a change in our mental substrate but rather as a threat to our existence” (Spaemann 2010, p. 9). This is why people of all ages have searched for means to cope with death, to gain immortality. Even if we deny that the problem of death exists, and if we imagine that there is no death (which is nowadays very common and also significant), death will sooner or later affect us. So, the problem remains, even if we deny it: the solution that we choose when we choose nothing is not a real solution at all - it is just a postponement of the solution.

But there is another possibility and this is to face the problem of death. For a long time, religion (relying on revelation and faith) and philosophy (relying on human own capacity of reason) have been offering different solutions. Both religion and philosophy were always tightly connected with anthropology as a basis of understanding of human being, especially the relation between mind (soul) and body ${ }^{3}$. Hellenistic philosopher Epicurus (341-270 BC) had already emphasized that it is important how we comprehend death. Only on the basis of our understanding of it we find death threatening or not. Epicurus is known as a materialist and hedonist. He regarded good as a pleasure, and bad as a pain. But pleasure and pain cease to exist after death because the body is destroyed; both of them are closely connected with it. Death is a complete annihilation. Therefore we do not need to be afraid of death. Epicurus summed up his theory in his famous thought found in his Letter to Menacceus: "So death, the most frightening of bad things, is nothing to us; since when we exist, death is not yet present, and when death is present, then we do not exist” (Epicurus 1994, pp. 28-31).

However, human beings are mostly not satisfied with such cold, rational solutions, at the end of which everything brings to annihilation. Human wants to exist also after death. This desire for immortality is something universal ${ }^{4}$. From the first known civilizations till the modern times, human have never stopped

\footnotetext{
${ }^{1}$ Goldman said: "I made up a hypothetical magic pill. I told them they'd win every competition for five years, but then die from it” (Sports Illustrated 2003).

2 Petra Majdič, cross country skiier from Slovenia, who won Olympic bronze medal on 2010 winter Olympics in Vancouver after serious injury in the first run, said: "It was worth. I would do it again. Was it worth risking life? Yes.” (MMC RTV Slo, 2011)

${ }^{3}$ For a short introduction to main arguments for immortality of body and immortality of soul see Zagzebski (2007, pp. 168-189) and Nagel (1987, pp. 87-94).

${ }^{4}$ See as example: Plato, Symposion 206a; Aquinas, Summa Theologicae I, 75, 6; Zagzebski (2007, p. 171).
} 
searching for the means and ways to reach immortality. Socrates and Plato gave the first philosophical arguments for it, grounded on a specific dualistic anthropological understanding of man as composed from body and soul. The soul is something immaterial and therefore unchangeable and immortal, while the body is material and therefore changeable and mortal. Because the essence of a human being is soul and not body ${ }^{5}$, he can live after the death of the body ${ }^{6}$. Plato, as some other religious sects and philosophical schools, believed in reincarnation of soul, however this view was not widely accepted among the Greeks (Taylor 2003, p. 24). In addition to this understanding of immortality, another more empirically grounded concept of immortality also appeared in ancient Greek culture. It was as kind of 'symbolic' immortality, the survival by immortal fame (Jonas 1962), which was also important for ancient athletes.

\section{Survival by immortal fame}

In ancient Greece the survival by immortal fame was highly appreciated. It was not only a proper reward for noble deeds, but also the main motive for them. But to find different deeds as important and to remember them as great, they must be visible, that is, public ${ }^{7}$. And public manifestations as athletic competitions were for Greek competitive (agonistic) human being a perfect mean for attaining this kind of immortality. "The single aim in all Greek athletics was - as the etymology (from athion, 'prize') suggests to win. There were no awards for second place” (Segal 1967, pp. 606-607 in Weiss, 1969, p. 175). With victory in a competition the athlete not only showed his predominance over other competitors but also his virtue - areté. The main endeavor of a talented young Greek man was to be first and to be seen in front of the others. Competitiveness was very characteristic for the Greek culture (Burckhardt 2002, p. 54). They competed in arts, rhetoric, and sport. Their word for competition was agon. Burckhardt therefore named the era before the $5^{\text {th }}$ century B.C. the 'agonal era.' At that time agon was incessant need for external confirmation and recognition, and its meaning was in "achieving eternal youth and equality with gods" (Zore 1997, p. 31), that is, a kind of immortality. We can read about this ideal in ancient Greek culture in Plato's work Symposion, where seer Diotima said:

"Think only of the ambition of men, and you will wonder at the senselessness of their ways, unless you consider how they are stirred by the love of an immortality of fame. They are ready to run all risks greater far than they would have run for their children, and to spend money and undergo any sort of toil, and even to die, for the sake of leaving behind them a name which shall be eternal. Do you imagine that Alcestis would have died to save Admetus, or Achilles to avenge Patroclus, or your own Codrus in order to preserve the kingdom for his sons, if they had not imagined that the memory of their virtues, which still survives among us, would be immortal? Nay,' she said, 'I am persuaded that all men do all things, and the better they are the more they do them, in hope of the glorious fame of immortal virtue; for they desire the immortal".

It was very important for a man to prove himself in the public sphere through admired acts that made him recognized, so other people would remember him after his death, praise him, and keep him in their memory. In times when transcendental immortality was not known (or accepted), this was the only mean to become immortal ${ }^{9}$. Even today the list of ancient Greek Olympic champions has survived, and we can still

\footnotetext{
5 "But since neither the body nor the combination of the two is man, we are reduced, I suppose, to this: either man is nothing at all, or if something, he turns out to be nothing else than soul.” (Plato, Alcibiades 1, 130c).

${ }^{6}$ Aquinas, similar to Plato (Symposion 206a), offers an interesting argument for the immortality of soul on the basis of desire: "Everything that has an intellect naturally desires always to exist. But a natural desire cannot be in vain. Therefore every intellectual substance is incorruptible” (The Summa Theologica I, 75, 6).

7 "This was most prized in antiquity and considered not only the just reward of noble deeds but a prime incentive to them. The deeds must be visible, that is, public, to be noted and remembered as great” (Jonas 1962).

${ }^{8}$ Plato, Symposion, 208 c-e.

${ }^{9}$ Similarly, Karen Joisten wrote regarding ancient Greek anthropology and sport: "Why could the athlete face this risk of losing his life in such a manner? What understanding did he have of himself? What understanding did he have of life and death? Then the answer becomes apparent: He put his life at risk because he wanted to win everything, that being: immortality" (Joisten 2007, p. 25).
} 
admire their statues and read Pindar's odes praising them. So, in a way, ancient sport champions are still alive - they achieved immortality, which they desired.

Hannah Arendt (1906-1975) derived the Greeks' concern with immortality from their experience of an immortal nature and immortal gods, which together surrender the individual life of mortal men. She asserted that

the task and potential greatness of mortals lie in their ability to produce things - works and deeds and words - which would deserve to be and, at least to a degree, are at home in everlastingness, so that through them mortals could find their place in a cosmos where everything is immortal except themselves. By their capacity for the immortal deed, by their ability to leave nonperishable traces behind, men, their individual mortality notwithstanding, attain an immortality of their own and prove themselves to be of a 'divine' nature (Arendt 1958, pp. 18-19).

Therefore, it was not a coincidence that ancient Greeks saw "every champion as from gods rewarded human being” (Zupanc 1997, p. 25).

With the rise of metaphysic within ancient philosophy (Socrates, Plato, Aristotle) and the Christian transcendental understanding of immortality, so also the need to be famous, to stay alive in the collective memory declined. This is also why in the Middle Ages artists often did not sign their works, because they did not feel the need for their recognition after death. But nowadays, when faith in transcendental immortality is loosing its public meaning, once again the ancient notion of immortality is becoming more and more powerful.

Social psychiatrist Robert Jay Lifton (1926- ), who coined the term "symbolic immortality", demonstrated that the sense of symbolic immortality is an essential prerequisite for mental health. It "gives meaning to our existence by preserving our connection to others in material ways in this life while ensuring our continued symbolic connection to others once we have left this mortal coil” (Lifton 1974 in Vigilant \& Williamson 2003, p. 173). Lifton proposes that we can gain symbolic immortality in five different modes, which he identifies as biological, creative, transcendental, natural, and experiential transcendence. For our purposes, the most interesting is the second mode of achieving symbolic immortality through creative acts, because sport activities themselves could be recognized as creative acts. Just as with art, literature and music, the sports achievements, results, and records also live on after their creators have died. It is worth noting that in competitive sports, results and records are empirically measured, statistically processed and after that, are carefully kept. And that is the essential condition to keep the "postself" after biological death ${ }^{10}$. With mechanisms of symbolic immortality, people are able to reduce death anxiety by achieving a sense of mastery over mortality, and this mastery is essential for psychological wellness.

Similarly, philosopher Georg Wilhelm Friedrich Hegel (1770-1831) affirmed that the fundamental desire of a human being is the desire for recognition ${ }^{11}$. For Hegel, human existence is unthinkable without bloody war for prestige, conflicts in which, paradoxicallly, "man wil risk his biological life to satisfy his nonbiological desire” (Kojève 1969, p. 41). The value of nonbiological desire for recognition surpasses

\footnotetext{
${ }^{10}$ Similar to symbolic immortality is the concept of the "postself." Edwin S. Shneidman (1918-2009) described that the postself consists of a person's reputation and continued influence after death. He delineated five ways in which the self can live on after death: a) in the memories of those who are still living, b) through the interactions others have with the deceased's creative works (art, music, books, and so on ),c) in the bodies of others, as in the case of organ transplants; d) in the genes of the deceased's progeny, and e) in the cosmos (Vigilant \& Williamson 2003, p. 175). Shneidman used the postself also as a therapeutic tool in helping dying patients (Kamerman 2003, p. 302).

${ }^{11}$ Alexandre Kojève, in his Introduction to the reading of Hegel, wrote about this: "However that may be, the human reality can be begotten and preserved only as 'recognized' reality. It is only by being 'recognized' by another, by many others, or-in the extreme-by all others, that a human being is really human, for himself as well as for others. And only in speaking of a 'recognized' human reality can the term human be used to state a truth in the strict and full sense of the term” (Kojève 1969, p. 9).
} 
biological life. We saw that this is the case also in Goldmann's research among athletes. It seems the possible reason for this is the (un)conscious belief in symbolic immortality.

Also, August Comte (1798-1857), the father of modern positivism, was in his own time deeply aware that it was not possible to avoid the problem of immortality, so he tried to answer this question. In accordance with his positivistic belief in humanity, he stressed what he called subjective immortality - to stay in the memory, thoughts, and love of those who know us, remember us, and esteem us. This is the concept of immortality, which ancient Greeks emphasized and which can be found in modern culture and sport. Being famous, recognized from among others, always in the memories of others - this can be recognized as one of the causes for trying hard to become a star, to become a champion in the field of sport nowadays.

\section{Sport as a means to achieve immortality}

Let us return to the interesting findings of Bob Goldman regarding relationships between top-level athletes, competition, winning, life, and death. In each of Goldman's surveys, more than $50 \%$ of the surveyed athletes said that they would take a magic drug to win, despite the fact that they would die after five years. From what has been said it seems reasonable to conclude that human's endeavor for immortality is once again (following ancient times) revived and highly appreciated among modern athletes. Top-level public sport, as covered by mass media, seems to be a perfect means for attaining survival by immortal memory and immortal fame. Remember, all halls of fame and all lists of ancient and modern Olympic champions that are still "alive".

Schmitt and Leonard (1986), in their paper "Immortalizing the Self Through Sport" come to similar conclusions. They research the processes through which Americans seek to leave their mark through achievement in sport. They conceptualize the 'postself' as an idealized role-identity that links the present to the future and to the past. It is the process through which individuals seek to "leave their footprints ... on the sands of time” (Schmitt \& Leonard 1986, p. 1089). Therefore, it is very important how athletes present themselves to the public and how they would like to be remembered (Cortese 1997). This can at least partly explain why so many athletes stop competing when they are still on the top of their athletic performance.

Allen Guttmann, historian of sport, also recognized the desire for immortality as one of the characteristics of modern sport. In his book Games and Empires (1994) he connects immortality with the modern obsession with records in sport:

"The unsurpassed quantified achievement, which is what we mean by 'record' in this uniquely modern usage, is a constant challenge to all who strive to surpass it and thereby to achieve a modern version of immortality” (Guttmann 1994, p. 3).

If we take a step further in our speculation, we can assert that this, at least in some part, explains the use of banned drugs in sport. Athletes use them even though that they know that they are dangerous because of health risks and that they could be caught using them. There is doubtless only one answer to the question, Why do athletes use banned substances? - To be the best, to win! But that answer rises another question, Why is winning so important? As we have seen money can be one answer, bodily perfection can be the other answer and fame and survival in memory (symbolic immortality) can be the third possible answer. What is even more interesting, even paradoxical, is that athletes can gain glory and survival by immortal fame regardless of whether or not they are caught in a doping test. If they won because banned substances helped them and they are not caught, they gain immortal fame, which they desired. But also if they are caught using prohibited drugs, they gain immortal fame. We all remember the example of Ben Johnson, famous from the 1988 Seoul Olympics, who was found guilty using steroids after winning the 100 meter dash. If we look at it from this standpoint, it does not matter if he was caught or not - he attained survival in immortal memory. His name is forever written in the history of the Olympic Games. Of course, it is another question of whether or not he wanted it. 
Now the question arises, is this hypothesis correct or not. In Goldman's surveys, not all the athletes were ready to take the magic pill, to become the winner, to gain public recognition and fame but after that for ever disappear from the surface of the earth. 'Only' a little more than a half of all the surveyed athletes said that they would take a magic pill. That result, however, differed enormously from what research found when they tested so-called Goldman's dilemma on the general population. A random survey of 250 members of the Australian general public reported that only two would take the bargain offered by the dilemma. The researchers concluded that athletes differ markedly from the general population, at least in terms of the response to the dilemma (Cannor \& Mazanov 2009). It seems that the athletes are much more aware of the whole picture of what is going on and what all is included in winning. They already train hard to win; they already completely subordinated their life to this goal but perhaps without success. So their decision seems much more reasonable.

The other question is how many athletes would in reality decide to take the offered pill if someone would come to them and offer them drug in front of them. What Goldman made is just a kind of thought experiment among athletes. But in real situation, when the decision made would have real consequences for athlete's life and death, their decision could be totally different. Human wisdom teaches us that only in the situations when we are face to face with death, the human life gets its real value.

Regarding sport as a means to gain symbolic immortality, the question arises: how many athletes in reality decided to be involved in top-level sport just because of their desire to become famous (and gain symbolic immortality)? Regarding this we can distinguish intentional and unintentional fame and/or immortality. Some people start training with or without possible fame or symbolic immortality on their minds. However, we know that only maybe $1 \%$ of those who start training achieve more visible results in their sport. But when parents bring their children to the gym in order to practice some specific sport in specific sports club, there could be behind their act the secret intention for their child to become successful and famous. This is more likely in cases when parents enroll their child in the sport or sports club, which, at the particular time, achieves better results (on local or international levels) ${ }^{12}$.

Beside that, it would be interesting to conduct a survey similar to the Goldman's dilemma among athletes from different types of sports. It seems that two important variables would be the mass media coverage of a particular sport as well as the financial status of that sport. It is reasonable to expect that for athletes from sports with better media coverage and lower financial income, the idea of gaining fame and immortality would be more in favor than among the athletes from sports that are not covered by mass media or from sports which provide high levels of financial income for athletes. Furthermore, it is reasonable to expect that among the athletes who are more inclined to accept the Goldman offer and gain immortal fame would be more athletes partipating in individual sports than athletes from team sports.

However, even though if sport (consciously or unconsciously) serves as a goal to attain symbolic survival by immortal fame, many thinkers express doubts in this kind of immortality. One of them is Hans Jonas, who points out that "the dimension of this living-on is the dimension itself in which it is earned: the body politic. Immortal fame is thus public honor in perpetuity, as the body politic is human life in perpetuity" (Jonas 1962, p. 2). Therefore, it is just the kind of immortality in time, which is, besides that, a tight connection and dependence on a community that preserves it. Although this kind of immortality is limited in time, there are known examples of ancient athletes (winners and also those athletes caught cheating) whose symbolic immortality is prolonged until today, that is, deep into the third millennium of existence. That is - regardless that ancient athletes could not expect that in real - reward that also bonds modern athletes to their extremely high daily efforts. But this kind of 'selective immortality' - which includes only the minority and excludes the majority - is doubtful also because of unjust selection. For modern man, who is aware of a modern way of producing fame and of the possible manipulation of public

\footnotetext{
${ }^{12}$ For example, in the years 1996/97 and 1997/98, when Slovenian ski jumper Primož Peterke won the World Cup, the interest for training ski jumping rise significantly in the Slovenian youth population. Also, many parents decided to enroll their children in ski jumping clubs around the country.
} 
opinion, this kind of immortality is insecure. After we die, control of our postself image is in the hands of our family, friends, fans, etc. Aristotle has already wisely pointed out that honor is worth just as much as the judgment of those who bestow it:

"But [honor] seems too superficial to be what we are looking for, since it is thought to depend on those who bestow honor rather than on him who receives it, but the good we divine to be something proper to a man and not easily taken from him" ${ }^{\text {" }}$.

Because of that, honor cannot be real 'good'; real good must be our own property, which means it must depend on us. Further, Aristotle found out that we seek honor and fame only as a means (and not as an end in itself) to get confirmation from outside for our own good. However, immortality can be an end in itself.

Doubts about immortality in fame were also presented by Jacques Maritain (1882-1973). He said that if that would be true immortality, than "lexicons, which are in help to human memory, would become museums of immortality” (Maritain 2004, p. 37). This kind of immortality would be proper only for different (philosophical) ideas and things in the corporeal word, but not for a human person. At the same time, immortality in fame would become real immortality only if there would be real 'objective' immortality, that is, if memory or human soul in fact would be immortal.

\section{Conclusion}

Although modern man is not favorable to the idea of immortality, the human being has been since ancient times asking the question how to defeat death and become immortal. It is even possible to say that the desire for immortality, to live eternally, is close to universal. Ancient thinkers as well as modern ones try to give different kinds of solutions to this problem. Besides meta-physical (immortality of soul - usually supported by different religions) and more empirical understanding of immortality - symbolic survival by immortal fame - arose in antiquity. Ancient athletes bet on this option because this was very practical and the only realizable means to 'win against death'. Furthermore, it is interesting that this kind of immortality can be identified nowadays in modern sport (as well as in other public activities ${ }^{14}$ ). From the findings of Bob Goldman's survey presented at the beginning, it is possible to also conclude that some modern top-level athletes consciously or unconsciously bet on survival by immortal fame.

Nevertheless, sport can indeed help not only athletes but everyone to avoid what Susan Ertz once stated as: "Millions long for immortality who do not know what to do with themselves on a rainy Sunday afternoon".

\section{REFERENCES}

Aquinas, T. (1948). The Summa Theologica. New York: Benziger Bros.

Arendt, H. (1958). The Human Condition. $2^{\text {nd }}$ ed. Chicago: The University of Chicago Press.

Aristotle (350 BC). Nicomachean Ethics. Retrieved November 11, 2011, from http://classics.mit.edu/Aristotle/ nicomachaen.html

Bamberger, M., \& Yeager, D. (1997). Over the edge [Electronic version]. Sports Illustrated, 86(15). Retrieved November 8, 2011, from http://sportsillustrated.cnn.com/vault/article/magazine/MAG1009868/index.htm

Bickar, J.C. (2006). Excellence and Ethics in Olympic Sports [Electronic version]. GoodWork® Project Report Series, 47. Retrieved November 11, 2011 from http://pzweb.harvard.edu/eBookstore/PDFs/GoodWork47.pdf

Burckhardt, J. (2002). History of Greek Culture. New York: Dover Publications.

\footnotetext{
${ }^{13}$ Aristotle, Nicomachean Ethics, p. 1095b.

${ }^{14}$ Even to publish a paper in an internationally recognized journal can be understood as attempt to gain symbolic immortality - similar to winning an important and well observed international sports competition. Benjamin Franklin (1706-1790), one of the Founding Fathers of the United States, once said: "If you would not be forgotten as soon as you are dead and rotten either write things worth reading or do things worth the writing”.
} 
Cannor, J.M., Mazanov, J. (2009). Would you dope? A general population test of the Goldman dilemma [Abstract]. British Journal of Sports Medicine, 43, 871-872. Retrieved November 11, 2011 from http://bjsm.bmj.com/content/ 43/11/871.abstract. DOI:10.1136/bjsm.2009.057596.

Cortese, A.J. (1997). The Notre Dame Bengal Bouts: Symbolic Immortality through Sport. Journal of Sport Behavior, 20. Retrieved November 11, 2011, fromhttp://www.thefreelibrary.com/The+Notre+Dame+Bengal+Bouts\%3A+ symbolic+immortality+through+sport.-a020139673

Epicurus (1994). The Epicurus Reader. Indianapolis: Hackett Publishing Company.

Goldman, B. (1984). Death in the locker room: Steroids \& sports. South Bend: Icarus Press.

Goldman, B. (1992). Death in the locker room II: Drugs \& sports. Chicago: Elite Sports Medicine Publications.

Guttmann, A. (1994). Games and Empires. New York: Columbia University Press.

Joisten, K. (2007). Man, mortality and the Athletic idol - Yesterday and Today. In D. Mieth, N. Muller \& C. Hubenthal (Eds.), Sport and Christianity. An Anthropological, Theological, and Pastoral Challenge (pp. 18-46). Mainz: Catholic Academy of the Diozese.

Jonas, H. (1962). Immortality and modern temper. Harward Theological Rewiew, 55(1), 1-20.

Kamerman, J. (2003). The Postself in Social Context. In C.D. Bryant (Ed.), Handbook of Death \& Dying (pp. 302-306). London: Sage Publications.

Lifton, R.J. (1974). On Death and the Continuity of Life: A 'New' Paradigm. History of Childhood Quarterly, 1, 681696.

Maritain, J. (2004). Po navdihu Tomaža Akvinskega /By inspiration of St. Thomas Aquinas/. Celje: Mohorjeva družba. MMC RTV Slo. (2010, March). Video: Petra pravi, da je bilo vredno tvegati življenje /Video: Petra said that it was worth risking life/. Retrieved November 8, 2011 from http://www.rtvslo.si/sport/preostali-sporti/olimpijske-igre2010/video-petra-pravi-da-je-bilo-vredno-tvegati-zivljenje/224719

Nagel, T. (1987). What Does It All Mean? A Very Short Introduction to Philosophy. Oxford: Oxford University Press. Plato (2004). Zbrana dela I \& Zbrana dela II /Collected works I \& Collected works II/. Celje: Mohorjeva družba.

Schmitt, R.L. \& Leonard, W.M. (1986). Immortalizing the self through sport. American Journal of Sociology, 91(5), 1088-1111.

Segal, E. (1967). It is Not Strength, But Art, Obtains the Prize. The Yale Review, 56(4), 605-609.

Spaemann, R. (2010). Essays in Anthropology. Oregon: Cascade Books.

Sports Illustrated. (November 26, 2003). Easily obtained steroids focus of debate. Retrieved November 8, 2011, from http://sportsillustrated.cnn.com/2003/more/11/26/us.doping.ap/

Taylor, M.R. (2003). Dealing With Death: Western Philosophical Perspectives. In C.D. Bryant (Ed.), Handbook of Death \& Dying (pp. 24-33). London: Sage Publications.

Vigilant, L.G., Williamson, J.B. (2003). Symbolic Immortality and Social Theory: The Relevance of an Underutilized Concept. In C.D. Bryant (Ed.), Handbook of Death \& Dying (pp. 173-182). London: Sage Publications.

Weiss, P. (1969). Sport; a philosophic inquiry. Illinos: Southern Illinois University Press.

Zagzebski, L.T. (2007). Philosophy of Religion; an historical introduction. Oxford: Blackwell Publishing.

Zore, F. (1997). Obzorja grštva: logos in bit v antični filozofiji /The horizons of Greek: Logos and being in ancient philosophy/. Ljubljana: Znanstveno in publicistično središče.

Zupanc, M. (1997). Cerkev in šport /Church and sport/. Bachelor's thesis, Ljubljana: Univerza v Ljubljani, Fakulteta za šport.

AUTHOR'S ADDRESS: Jernej Pisk

Losca 46

1360 Vrhnika, Slovenia

Email:jernejpisk@gmail.com 